\title{
可燃性廃棄物のプラズマ炉内一括燃焼処理方法の基礎検討 ${ }^{\dagger}$
}

\author{
安井晋示 ${ }^{\dagger \dagger}$ ・天川正士
}

(財) 電力中央研究所, 240-0196 横須賀市長坂 2-6-1

\begin{abstract}
低レベル放射性雑固体廃棄物として金属, 無機物とともに混在して保管されている可燳物を一括してプ ラズマ溶融処理する手法を開発するために, 廃棄物に含まれる代表的な可燃物であるポリエチレン (PE) のプラズマ炉内での燃焼処理条件を実験的に検討した.PEのプラズマ炉内での熱分解・燃焼速度をPE の投入重量と形状光して炉内注入空気量に対して調へ，PEの炉内反応速度は，PE の形状と注入空気量の 処理条件に依存しないことを明らかにした。また，本研究で得た見かけの速度定数を用いることで，スケ 一ルアップ時に，一度の投入で燃焼処理したいPE の重量からプラズマ炉内で燃焼処理するために必要な 炉内滞留時間を推定できる見通しを得た。
\end{abstract}

\section{緒言}

プラズマ溶融は, 被加熱物の性状によらず高温で安定した加熱 が可能であることから, 特に, 固体状廃棄物の減容処理技術とし て優れている.この技術は, 都市ゴミ焼却灰の溶融無害化処理手 法として実用化されている。現在, 低レベル放射性雑固体廃棄物 の減容処理技術として，プラズマ溶融技術の適用が期待されてい る.すなわち, 低レベル放射性雑固体廃棄物には, 配管やボルト などの金属類, 保温材やフィル夕などの無機物そしてポリエチレ ン袋や塩化ビニル管などの可・難燃物が含まれる．保温材の中に は融点の高いものがあり, また, 可燃物は金属や無機物と分別し にくい形態で存在している。これらの廃棄物をプラズマ炉内で一 括して溶融処理できれば，分別行程を省略できるとともに，廃棄 物の高温処理設備を複数導入する必要がなくなり有益となる.

我々は, 杂固体廃棄物一括減容処理へのプラズマ溶融法の適用 性評価を $100 \mathrm{~kW}$ のプラズマ溶融炉を用いた基礎実験により行っ ている.これまでに, 非放射性の核種模擬元素を添加した金属, 無機物, 可燃物の廃棄物模擬試料を一括プラズマ溶融処理し, 溶 融処理物の性状を明らかにし，均質で核種閉じこめ性に優れるな ど埋設処分に適する溶融固化体が作製できること等を確認した (Amakawa et al., 1995 ; Yasui et al., 1998). しかし, 溶融処理 時に可燃物の投入速度を速くすると，排がス中にすすが大量に排 出されるとともに，プラズマ炉内が連続的に強い還元性の雲囲気 となり，廃棄物に付着しているアルカリ金属の蒸発が促進される ことが判明した（Yasui et $a l .$, 1998). 廃棄物に付着している金 属類は, 溶融処理時に溶融固化体の中に閉じこめることが望まし い.また，すすは，炉内で完全燃焼しきれなければフィル夕の目 詰まりの原因になり，後流の燃焼器の負荷が増大するなど排がス 処理装置の負担を大きくする，このため，可・難燃物は，プラズ マ炉内でできるだけ完全燃焼することが望まれ，炉内で極力完全 燃焼させるための処理条件を摘出することが, 一括溶融処理技術 の開発において重要となる．可・難燃物をプラズマ炉内で適切に 燃焼処理するためには，処理条件に対する可・難燃物の炉内燃焼 速度を把握する必要がある. 本報告は, 可燃物試料として, 雑固 体廃裹物中に多く含まれるポリエチレン（PE）を用い, プラズマ

$† 1998$ 年 7 月 24 日受理

†† shinji@criepi.denken.or.jp
炉内での燃焼速度を実験的に調べ, 完全に燃焼処理するための処 理条件を検討した結果をまとめたものである.

\section{1. 実験方法}

\section{1 可燃物の炉内燃焼速度の推定手法}

本研究では, すすの発生を防止し, 炉内が強い還元性の雾囲気 とならない可燃物の処理条件の基準として, 排がス中に $\mathrm{CO}$ が $0.1 \mathrm{Vol} \%$ 以上検出されないこととした.この理由は, 金属と不燃 物に加之, 可燃物を空気比 [可燃物を完全燃焼させるために必要 な空気量（可燃物の一回の投入重量と投入間隔から算出した）に 対する注入空気量の比率をを変化させて一括溶融処理した実験結 果において, 排がス中の $\mathrm{CO}$ 濃度が $0.1 \mathrm{Vol} \%$ 以上とならない可 燃物の投入処理条件で，アルカリ金属の溶融固化体中への残存率 が不活性および酸化性の雾囲気条件で行った場合と有意な差がな い結果を得たことによる (Yasui et al., 1998). また, プラズマ 炉内での可燃物の燃焼速度を, 可燃物が炉内で完全燃焼した時に 発生する $\mathrm{CO}_{2}$ の排がス中濃度の経時変化から推定した. Fig. 1 に $\mathrm{CO}_{2}$ 濃度の経時変化から炉内燃焼速度を推定する手法を示す. 排 ガス中に $\mathrm{CO}_{2}$ が検出された時からの反応時間 $t_{1}$ に対する反応率 $X_{1}$ を反応時間 $t_{1}$ までの $\mathrm{CO}_{2}$ 濃度の積分值が全積分值に占める割 合とし， $\mathrm{CO}_{2}$ が検出されなくなった (濃度：0.1 Vol\% 未満) 時間 を反応完了時間 $\tau$ とした。この手法で得た反応時間に対する反応 率の関係を気固反応の速度式を用いて数式化した.

\section{2 実験装置と実験条件}

実験で用いたプラズマ炉の概略図を Fig. 2 に示す.プラズマ炉 は, 空気注入口, 可・難燃物投入口, 排ガス吸引口, 炉内観察空 を有する. 溶融るつぼは, 内径 $230 \mathrm{~mm}$, 梁さ $220 \mathrm{~mm}$ のアルミナ 製であり，水冷のステンレス製容器の中に粒状の耐火材で固定し た.プラズマトーチは電極に酸化ランタン入りタングステンを用 いたロッドタイプであり，プラズマガスとしてアルゴン（10N $l /$ min）を用いた。 空気の注入は, プラズマ炉上部から内径約 2.5 cmのパイプを通して行った. 排ガスは, 分析がスをサンプリング した後，2次燃焼炉とスクラバーで未燃分の完全燃焼と除塵を行 い, 排出した. 分析がスは, $100^{\circ} \mathrm{C} に$ 加熱したテフロン管を通して 分析装置まで導き, $\mathrm{O}_{2}$ 濃度を磁気力式, $\mathrm{NO}_{\mathrm{x}}$ 濃度を減圧化学発光 法, $\mathrm{CO}, \mathrm{CO}_{2}, \mathrm{CH}_{4}$ の濃度を非分散型赤外線吸収法により連続的 に計測した。

実験では，まず, $15 \mathrm{~kg}$ の炭素鋼と $1 \mathrm{~kg}$ の珪酸カルシウム保温 


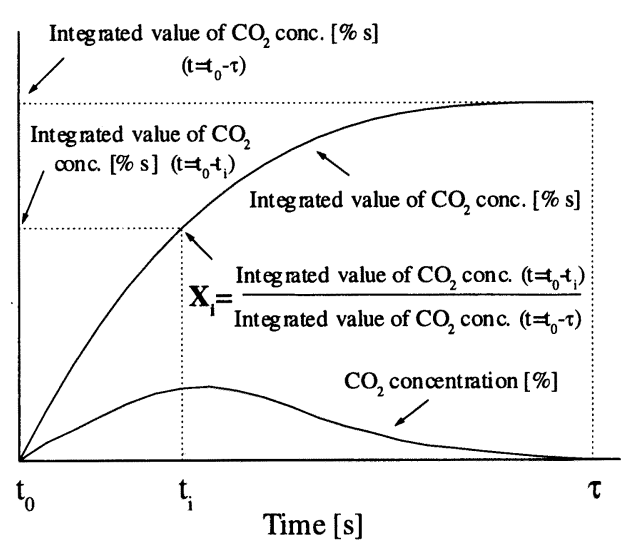

Fig. 1 Method for overall reaction rate analysis of combustible materials

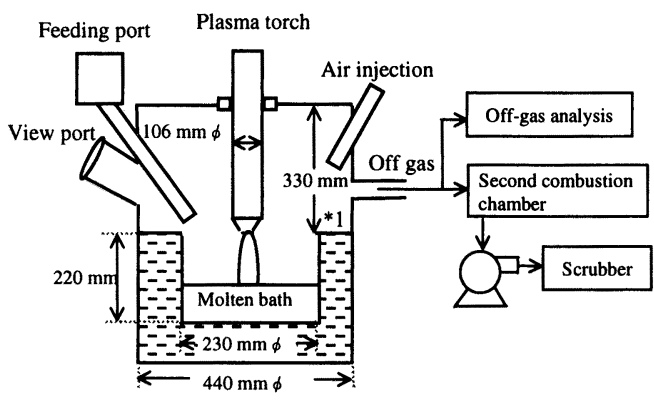

Fig. 2 The $100 \mathrm{~kW}$ class plasma melting system

材をプラズマ炬内に入れ，注入空気量を設定した後， $30 \mathrm{~kW}(300$ $\mathrm{A}, 100 \mathrm{~V})$ の移行型プラズマトーチにより溶融して溶湯を作製し た. 溶湯を完全に作製し, 炉内温度 (Fig. 2 に示した*1の測定場所) と排ガス中の酸素濃度が安定したことを確認してから, PEを投 入した. $\mathrm{PE}$ 投入実験中も $30 \mathrm{~kW}$ のプラズマを維持した. $\mathrm{PE}$ 投入 前の炉内温度は約 $700^{\circ} \mathrm{C}$ の值を示し, $\mathrm{PE}$ 投入時は実験条件 (PE 投入重量や注入空気量）により $100^{\circ} \mathrm{C}$ の範囲で変動した。また, 溶湯の温度は, 実験後に $\mathrm{R}$ 型熱電対で直接測定した值として $1,500^{\circ} \mathrm{C} \sim 1,600^{\circ} \mathrm{C}$ の範囲を示した。排ガス中の酸素濃度は，プラ ズマガスとしてアルゴンを流していること，溶湯作製時における 鉄の酸化反応により酸素が消費されることにより時間とともに減 少する。しかし，溶湯を作製した段階 (PE 投入実験前)でほぼ一 定值を示し, 注入空気量の条件により 12 17 Vol\% の範囲を示し た. $\mathrm{PE}$ 試料は, $1 \mathrm{~g}$ または $2 \mathrm{~g}$ 単位で定量し, 定量した試料を投 入口にセットし，バルブの開閉により溶湯上に自然落下させた. 実験パラメーターは, PE 投入重量と注入空気量とし，ペレット 状, シート状, チューブ状の 3 種類の形状の試料について実験を行 った。また，実験は，1条件につき $5 \sim 10$ 回行った。

\section{2. 実験 結 果}

\section{1 炉内燃焼状態と排ガス組成}

PE 試料が溶湯表面に落下寸ると, 急激に熱分解が起こり大量 のすすが発生するのが観察された。そして, 投入した PE は溶湯上 で徐々に小さくなり，それに伴ってすすの発生量も減少した。 そ の時の排ガス組成の一例として, $2 \mathrm{~g}$ の $\mathrm{PE}$ ペレットを 1 個投入し た時に検出された排ガス組成の経時変化を Fig. 3 に示す. 排ガス 中に検出された $\mathrm{CO}_{2}$ 濃度は, 検出後約 20 秒で極大值を示した後 に時間とともに減少した，また，酸素濃度は，投入ロバルブの開 閉の影響により投入直後に若干增加するものの, $\mathrm{CO}_{2}$ 濃度の上昇

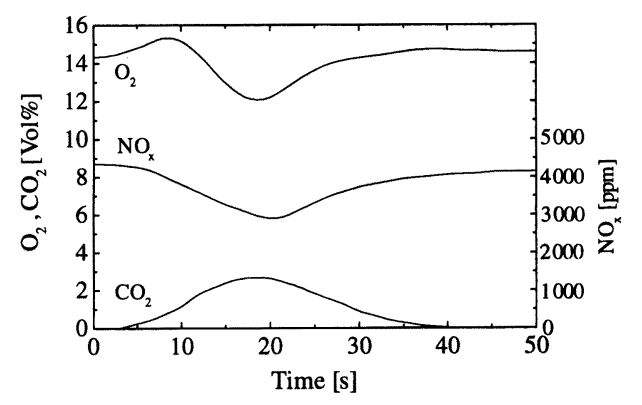

Fig. 3 Off-gas compositions during plasma incineration of PE weighting of $2 \mathrm{~g}$ at air flow rate of $50 \mathrm{l} / \mathrm{min}$

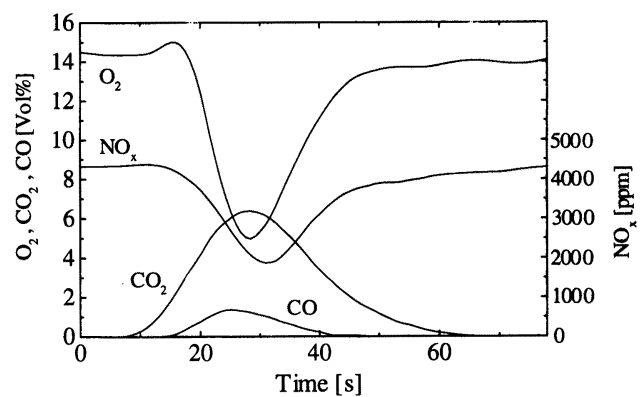

Fig. 4 Off-gas compositions during plasma incineration of PE weighting of $8 \mathrm{~g}$ at air flow rate of $50 \mathrm{l} / \mathrm{min}$

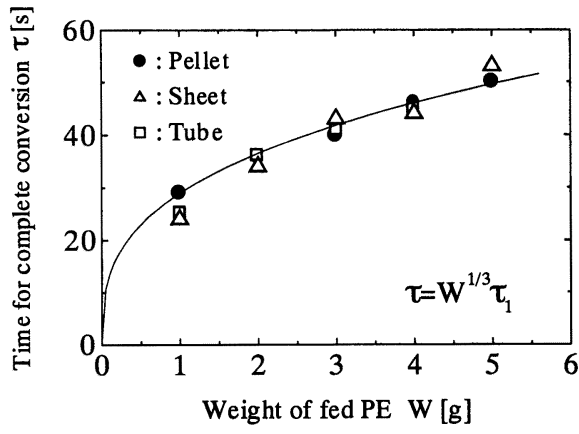

Fig. 5 Time for complete conversion versus weight of fed PE at air flow rate of $50 \mathrm{l} / \mathrm{min}$

とともに低下して $\mathrm{CO}_{2}$ 濃度が極大值をもつのとほぼ同時に極小 值を示した後, $\mathrm{CO}_{2}$ 濃度の減少とともに上昇して $\mathrm{PE}$ 投入前の状 態に復帰した.Fig. 4 に $2 \mathrm{~g}$ の PEペレットを 4 個同時に投入し た時の排ガス組成の経時変化を示す。この場合は, 排ガス中に $\mathrm{CO}_{2}$ とともに不完全燃焼ガスである $\mathrm{CO}$ が検出された. 本実験条 件では, PE 試料を一度に $4 \mathrm{~g}$ まで投入した範囲において，排がス 中に $\mathrm{CO}, \mathrm{CH}_{4}$ の可燃性がス成分が検出されなかった。この結果 は，検討した形状の試料すべてについて共通であった。

\section{2 処理条件と反応完了時間}

反応完了時間すなわち排ガス中の $\mathrm{CO}_{2}$ 検出時間と処理条件の 関係を調べた，同じ条件で繰り返し行った反応完了時間の結果の ばらつきは, 変動係数として約 $10 \%$ 以下であった. Fig. 5 に PE 投入重量に対する結果を示す。ここでは，それぞれの結果に対し 平均值のみを示した。反応完了時間は $\mathrm{PE}$ 試料の形状に依存せず, 投入重量 $W$ の $1 / 3$ 乗に比例して増加する結果を得た。この理由 を以下に推定する．炉内に投入した PEは溶湯上で急速に熱分解 し，PEが落下した溶湯上の局所的な場所からすすが大量に発生 した.この局所的な場所から急速に発生したす寸は 1 ないしは多 数の集団を形成し，それぞれの集団の中心部で酸素が局所的にゼ 


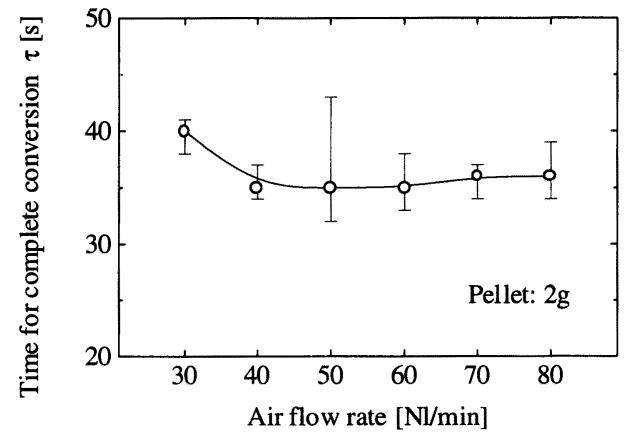

Fig. 6 Time for complete conversion versus air flow rate of PE pellet weighting of $2 \mathrm{~g}$

口に近い状態になったと考えられる，このため，すすは集団の周 辺部から除々に燃焼し，その反応完了時間が，発生したす寸集団 を球状で近似した場合の半径に比例したと考えられる。ささらに， 集団を形成するす寸の体積が PEの投入重量に比例して增加した ために, $\mathrm{PE}$ の反応完了時間が $\mathrm{PE}$ 投入重量の $1 / 3$ 乗に比例して增 加したと考えられる。また，反応完了時間が PE 形状に依存しなか った理由は，高温の溶湯上での PEの熱分解速度が $\mathrm{PE}$ の熱分解 生成物であるすすの燃烧速度に対して非常に速いためと考えられ る.

Fig. 6 に注入空気量を変化させた時の反応完了時間の結果を示 す. 注入空気量を $30 \mathrm{~N} l / \mathrm{min}$ とした条件で反応完了時間が長くな ったが，他の注入空気量の条件では差が生じなかった，注入空気 量を $30 \mathrm{~N} l / \mathrm{min}$ とした場合は PE 投入前の排がス中の酸素濃度 が $12 \mathrm{Vol} \%$ と低くなったが， $40 \mathrm{~N} l / \mathrm{min}$ 以上の条件では，PE 投 入前の酸素湛度が 15-17 Vol\% の範囲で大きな差が生じなかった。 この結果から, 注入空気量が $30 \mathrm{~N} l / \min$ の条件では, 炉内酸素浱 度の低下により PEの熱分解生成物であるすすの燃焼速度が遅く なったと考えられる. 注入空気量が $40 \mathrm{~N} l / \mathrm{min}$ 以上の条件で, 反 応完了時間に有意な差が生じなかった理由は，次節で考察する。

以上の結果から, 反応完了時間は, 炉内酸素濃度 15-17 Vol\%の 範囲において，以下の式で表すことができる。

$$
\tau=\tau_{1} \cdot W^{1 / 3}=W^{*(1 / 3)} / k_{\mathrm{a}}
$$

ここに， $W^{*}$ は単位重量 $(1 \mathrm{~g})$ で無次元化した PE 投入重量, $k_{\mathrm{a}}$ は見かけの速度定数であり, Fig. 5 に示した実験結果から見かけ の速度定数の值として $0.034\left[\mathrm{~s}^{-1}\right]$ を得た。

\section{3.}

\section{1 炉内燃焼速度の推定式}

排ガス中に $\mathrm{CO}$ などの可燃成分が検出されなかった PEの投入 重量範囲において，1.1節で示した手法により $\mathrm{CO}_{2}$ 濃度の経時変 化から反応時間 $t$ に対する反応率 $X$ を算出した。 それぞれの実 験条件で得た結果について, 反応時間 $t$ を反応完了時間 $\tau$ で除し て無次元化し, 無次元反応時間 $t *$ に対する反応率を求めた. そし て, 同じ条件で繰り返し行った結果について，無次元反応時間 $t^{*}$ に対する反応率の值の平均値を求めた。一例として, PEペレット の結果を Fig. 7 に示す. 全ての条件において，反応初期における 反応率の増加が非常に小さく，その後急速に増加する結果を得た. プラズマ炬内での熱分解・燃焼現象の観察結果から，PEの燃焼 速度がすすの燃焼速度に支配されていると考えられたため，無次 元反応時間に対する反応率の結果を気固反応の速度式を用いて数 式化した，気固反応の速度式の中で，細孔がない単一球状粒子の

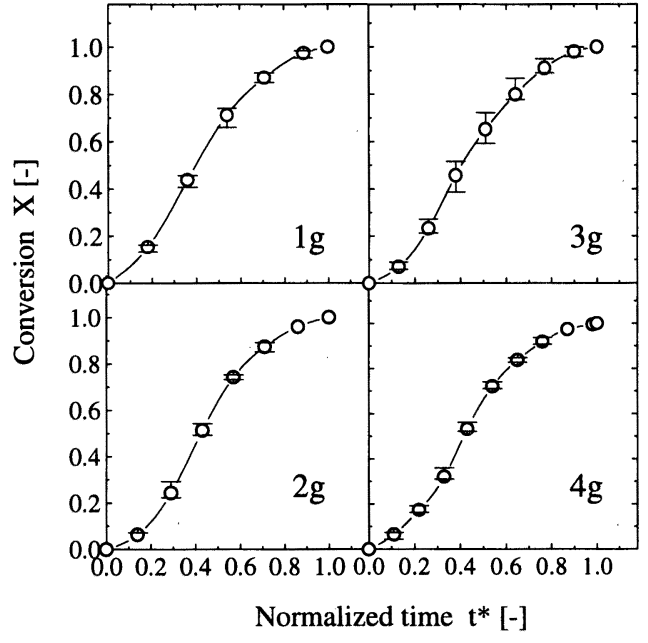

Fig. $7 \quad t^{*}$ versus $X$ of PE pellet at air flow rate of $50 \mathrm{l} / \mathrm{min}$

ガス化反応を想定した場合の反応時間と反応率の関係が，各律速 段階において以下の式で表されている（Szekely et al., 1976; kagakukougakkai, 1994).

表面反応律速

(大・小粒子) $\quad t / \tau=t^{*}=1-(1-X)^{1 / 3} \equiv f_{\mathrm{a}}(X) \quad(2)$

ガス境膜拡散律速

（大粒子） $\quad t / \tau=t^{*}=1-(1-X)^{1 / 2} \equiv f_{\mathrm{b}}(X)$

(小粒子) $\quad t / \tau=t^{*}=1-(1-X)^{2 / 3} \equiv f_{\mathrm{c}}(X)$

本研究で得た無次元反応時間に対する反応率の結果をこれらの速 度式に代入した。 それぞれの形状に対する結果を Fig. 8 に示す. この結果から, 反応率を $(3)$ 式の関数 $f_{\mathrm{b}}(X)$ に代入した值が, ほ ぼ $t^{*}>0.15$ の範囲において, 無次元反応時間に対して直線的に増 加した。また，この結果は，PE 試料の形状や投入重量を変化させ た場合についても同様となった。したがって, PE 試料の形状や投 入重量によらず，無次元反応時間に対する反応率の関係が，ほぼ $t^{*}>0.15$ の範囲において，(3) 式に係数を加えた下式で表すこと ができる。

$$
\begin{aligned}
& t^{*}=t / \tau=1-0.85 \cdot(1-X)^{1 / 2} \quad\left(t^{*}>0.15\right), \\
& X=0 \quad\left(t^{*} \leq 0.15\right)
\end{aligned}
$$

$t^{*}<0.15$ の範囲で $(3)$ 式の右辺の関数 $f_{\mathrm{b}}(X)$ 值が非常に小 さくなったこの理由は，PE 試料を投入した直後は， $\mathrm{PE}$ の熱分 解によるすすの発生が支配的となり，PEの燃焼量すなわち反応 率が小さくなったためと思われる.また, $\mathrm{PE}$ 試料の形状に依存し なかった理由は, 反応完了時間と同様, PEの熱分解速度が速く, PE の熱分解生成物であるすすの燃焼速度が律速となったためで ある. Fig. 9 に $2 \mathrm{~g}$ の PEペレット試料を注入空気量を変化させ て投入した時の結果を示す．注入空気量を変化させた場合におい ても, 無次元反応時間に対する反応率の結果を（5）式の関数型で 表すことができた.

ここで，無次元反応時間に対する反応率の結果が球状大粒子の ガス境膜拡散律速を仮定した速度式にフィットした理由を考察す る．前節で考察したように，溶湯上の局所的な位置から発生した 大量のすすは集団を形成すると考えられ，プラズマ炉内でのすす の燃焼現象が，微粒子であるす寸単独の燃焼現象ではなく，す寸 の集団としての燃焼現象となったと思われる。このため，炉内酸 素がす寸集団の中心部に向かう時の拡散速度が燃焼速度の律速と なるとともに，大粒子を仮定した式に反応率の結果がフィットし たと考えられる．しかし，前節において，反応完了時間が注入空 


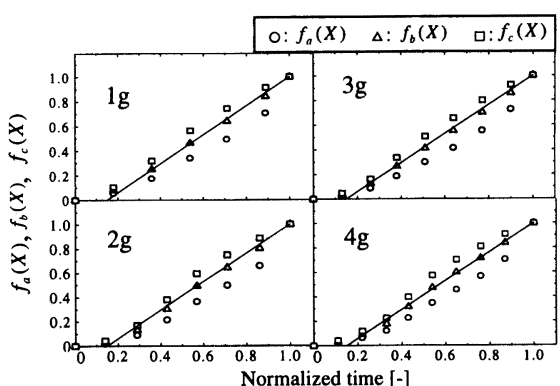

(a) Pellet

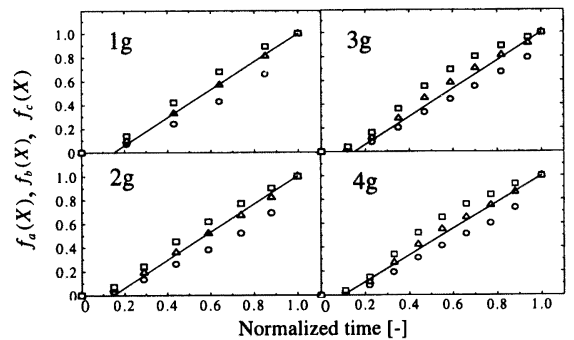

(b) Sheet

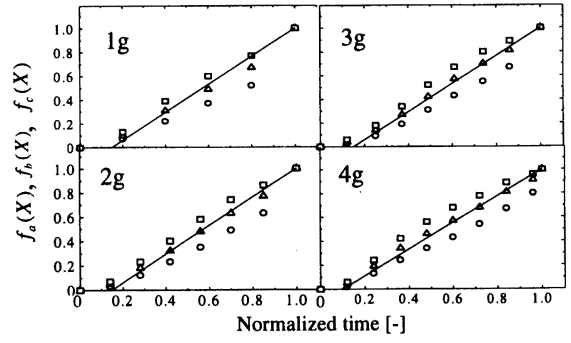

(c) Tube

Fig. $8 t^{*}$ versus conversion function of $\mathrm{PE}$ at air flow rate of $50 \mathrm{l} /$ min. (a) Pellet, (b) Sheet and (c) Tube

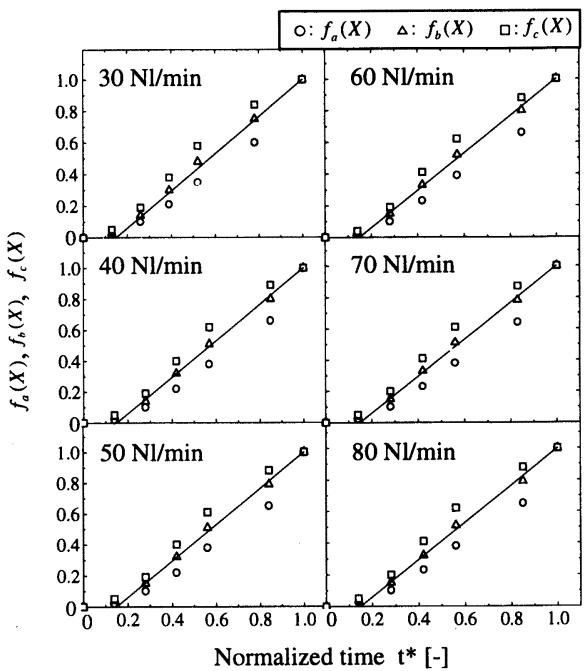

Fig. $9 t^{*}$ versus conversion function of PE pellet weighting of $2 \mathrm{~g}$

気量に依存しない結果を得た。この原因は，すすの燃焼速度に支 配的な影響を与えると思われるプラズマ炉内下部の高温領域が, 高速のプラズマ流により擋汼されており，炉上部から注入した空 気による摚拌力が炉内酸素の拡散速度に大きな影響を与えなかっ たものと考えられる。

\section{2 最大投入重量の推定手法}

プラズマ炉をスケールアップした場合に，一度の投入で適切に 燃焼処理できる可燃物の最大投入重量を推定する手法を検討した.

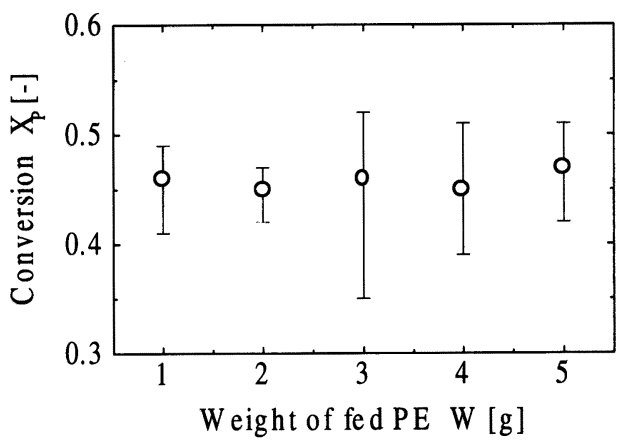

Fig. $10 X_{\mathrm{p}}$ of $\mathrm{PE}$ at air flow rate of $30-80 \mathrm{l} / \mathrm{min}$

可燃物を炉内で燃焼処理するための条件としては, 可燃物の熱分 解により発生するすすを炉内滞留時間内に燃焼することが挙げら れる. プラズマ炉内に可燃物を投入した場合は, 溶湯上での熱分 解により発生するすすの量が時間とともに変化する.この場合, 発生量が最大となった時のすすを炉内滞留時間内に燃焼できれば 良いと考えられる，すなわち，可燃物投入直後に発生したす寸は， 炉内酸素濃度も高いことから急速に燃焼するが, 発生量が最大と なる時のすすは燃焼とともに炉内酸素濃度が低下することから， 完全に燃之尽きるまでの時間を一番長く必要とする. そして, 発 生量が最大となる時のすすが燃え尽きた時に酸素濃度が極小值を 示し, $\mathrm{CO}_{2}$ 濃度も極大值を示すものと考えられる。したがって， プラズマ炉内で可燃物を燃焼処理するための条件としては, 可燃 物の熱分解によるすすの発生量が最大となる時から $\mathrm{CO}_{2}$ 濃度が 極大值を示すまでの時間を炉内滞留時間として確保することが必 要と考えられる.

各実験条件で得た $\mathrm{CO}_{2}$ 濃度の経時変化から, $\mathrm{CO}_{2}$ 濃度が極大值 を示す時の反応率 $X_{\mathrm{p}}$ を調べた結果を Fig. 10 に示す.この結果か ら, 反応率 $X_{\mathrm{p}}$ は $\mathrm{PE} の$ 形状や注入空気量などの処理条件に依存 せず，その平均值は 0.46 であった. また, 反応率が 0.46 となる時 の無次元反応時間は（5）式から 0.38 と算出できる.しかし, 可燃 物を炉内に投入して燃焼が開始されてから, 熱分解により発生す るすすの量が最大となるまでの時間を定量的に計測することは困 難である. したがって, ここでは, すすの発生量が最大となる時 間を無次元反応時間として 0.15 と仮定した.この理由は, 前節の 考察から, 無次元反応時間 0.15 を境として反応率が大きく増加し たことから，PEの熱分解によるすすの発生が支配的な状態から すすの燃焼が支配的な状態に変化したものと想定されたからであ る. したがって，一度の投入によりプラズマ炬内で適切に燃焼処 理するための $\mathrm{PE}$ 投入重量の条件は, $\mathrm{PE}$ の無次元反応時間 0.23 を炉内滞留時間として確保することと推定できる．この值を用い て，(1）式から PE をプラズマ炉内で適切に燃焼処理するための 炉内滞留時間 $t_{\mathrm{r}}$ の条件を下式として得る.

$$
t_{\mathrm{r}}=0.23 \cdot \tau=0.23 \cdot W_{\max }{ }^{*(1 / 3)} / k_{\mathrm{a}}
$$

ここに, $W_{\max }{ }^{*}$ は,一度の投入で燃焼処理できる $\mathrm{PE}$ の無次元最大 投入重量である.

本実験装置において，CO ガスをトレーサとして溶湯表面から 溶融炉出口までの滞留時間 $t_{\mathrm{r}}$ を注入空気量に対して調べた結果 を Fig. 11 に示す. 本研究で用いた注入空気量の条件において, 炉 内滞留時間は約 11 秒確保できている. また, 本研究で行った全て の実験条件で，一度に $4 \mathrm{~g}$ までの PE 試料であれば炉内で燃焼処 理できた。（6）式から，4g の PE 試料を燃焼処理するために必要 な炉内滞留時間を，(1) 式で得た見かけの速度定数 $k_{\mathrm{a}}$ の值 $0.034\left[\mathrm{~s}^{-1}\right]$ を用いて算出すると 10.7 [s] を得る. Fig. 12 に示すよ

第 25 巻 第 2 号 (1999) 


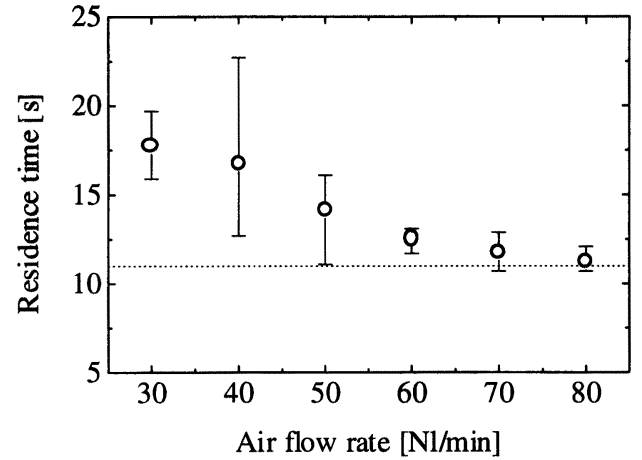

Fig. 11 Air flow rate versus residence time $t_{\mathrm{r}}$ of the plasma-melting furnace

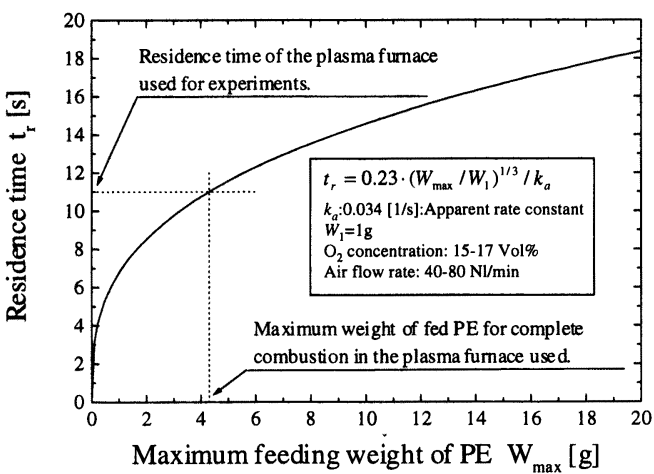

Fig. 12 Method for estimating the residence time of the plasma furnace from the feeding weight of $\mathrm{PE}$ waste materials for complete combustion

うに,この（6）式を用いた推定結果と実験的に求めた炉内滞留時 間が良く一致したことから，一度の投入により炉内で燃焼処理し たいPEの投入重量に対して，燃焼処理に必要な炉内滞留時間を， （6）式を用いて推定できる見通しを得た。この実験式は, PEの完 全燃焼に必要な酸素量がプラズマ炉内に十分確保できる範囲で適 用できるものと考えられる。

\section{結}

低レベル放射性雑固体廃棄物に含まれるポリエチレン $(\mathrm{PE})$ を，排ガス中にすすなどの未燃成分を排出しないようにプラズマ

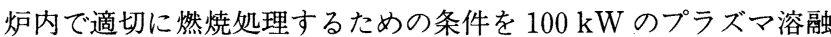
基礎実験炉を用いて検討し，以下を得た。

（1）排がス中に $\mathrm{CO}$ などの可燃成分が検出されない $\mathrm{PE}$ 投入重 量範囲において，排がス中の $\mathrm{CO}_{2}$ 検出時間を投入重量に対し て調べた結果，検出時間が投入重量の $1 / 3$ 乗に比例すること を明らかにし, 炉内酸素濃度が 15-17 Vol\%の範囲で, PEの
炉内熱分解・燃焼速度の見かけの速度定数として $0.034\left[\mathrm{~s}^{-1}\right]$ を得た。

（2）プラズマ炉内での PE 熱分解生成物の燃焼速度を，排ガス 中で検出した $\mathrm{CO}_{2}$ 濃度の経時変化から推定した結果, 無次元 化した反応時間に対する反応率の変化を（5）式の速度式と して得た.この速度式は, PEの投入重量や形状および注入空 気量などの処理条件に依存しないことを明らかにした。

（3）上記で得た見かけの速度定数を用い，スケールアップ時に 一度の投入で燃焼処理したいPEの投入重量から炉内で燃焼 処理するために必要な滞留時間を（6）式を用いて推定でき る.

[謝辞］本研究を行うにあたり, 電力中央研究所 横須賀研究所 プラント熱工学部 長谷川武治主任研究員, 同 エネルギー化学部 小林 誠主任研究員に有益な助言を受けた，また，本報告をまとめるにあたり，電 力中央研究所 横須賀研究所 エネルギー化学部 牧野尚夫部長にご指導 頂いた。ここに，付記して感謝の意を表します。

\section{Nomenclature}

$k_{\mathrm{a}}=$ apparent reaction rate constant

$t \quad=$ reaction time

$t_{\mathrm{r}} \quad=$ residence time of plasma melting furnace

$t^{*}=$ normalized time

$W=$ weight of combustible materials

$W^{*}=$ normalized weight of combustible materials

$W_{\max }{ }^{*}=$ normalized maximum weight of combustible materials

$X=$ conversion

$X_{\mathrm{p}}=$ conversion at maximum concentration of $\mathrm{CO}_{2}$

$\tau=$ time for complete conversion

\section{Literature cited}

Amakawa T., K. Adachi and S. Yasui ; "Fundamental Research on Thermal Plasma Technology for Treatment of Low-Level Radioactive Solid Waste," Electrical Engineering in Japan, 115, 1-9 (1995)

Szekely, J., J. W. Evans and H. Y. Sohn; "Gas-Solid Reactions," Academic Press, New York, U.S.A. (1976)

Yasui S., K. Adachi and T. Amakawa; "Influence of Atmospheric Gases on the Treatment of Miscellaneous Solid Wastes by Plasma Melting Technology," Int. Jour. Progress in Nuclear Energy, 32, 493 -500 (1998)

Kagakukougakkai ed.; Kagaku Kogaku Benran, 4 th Ed., P. 1092, Maruzen, Tokyo, Japan (1994) 


\section{Fundamental Research on Incineration Method for Combustible Wastes in Plasma Melting Furnace}

SHINJI YASUI and TADASHI AMAKAWA

Electrical Engineering Department, Yokosuka Research Laboratory, Central Research Institute of Electric Power Industry, Yokosuka 240-0196

Key words: plasma melting, low-level radioactive wastes, combustible wastes, polyethylene, simultaneous treatment, reaction rate.

In order to develop a treatment of low-level radioactive miscellaneous solid waste containing combustibles by plasma melting technology, the incineration of polyethylene (PE), the main combustible in the wastes, is examined by using a $100 \mathrm{~kW}$ plasma melting system. The overall reaction rate of $\mathrm{PE}$ in the plasma furnace is examined by changing the air flow rate, the feeding weight of PE, and the shape of $\mathrm{PE}$. The reaction rate is found to be independent of air flow rate, and the shape of $\mathrm{PE}$. The reaction rate is thus a function solely of weight of PE fed, and can be used to estimate the residence time of PE with a given weight required for complete incineration. 